\title{
TINJAUAN PUSTAKA \\ MINI CEX : METODE PENILAIAN PERFORMA PADA PENDIDIKAN TAHAP KLINIK
}

\author{
Detty Iryani \\ Bagian Pendidikan Kedokteran Fakultas Kedokteran Universitas Andalas \\ Bagian Fisiologi Fakultas Kedokteran Universitas Andalas \\ email : detty.iryani@gmail.com
}

\begin{abstract}
Abstrak
Mini Cex adalah salah satu metode penilaian yang dirancang untuk mengukur performa peserta didik dalam pendidikan tahap klinik. Penilaian Mini Cex dilakukan oleh seorang penilai yang sudah dilatih terhadap peserta didik yang berinteraksi langsung dengan pasien, yang terdiri dari tujuh komponen yaitu anamnesis, pemeriksaan fisik, profesionalisme, clinical judgment, keterampilan konseling, organisasi atau efisiensi dan penilaian secara keseluruhan. Berbagai penelitian menunjukkan bahwa metode penilaian ini memiliki validitas dan reabilitas yang baik, selain itu metode ini juga mempunyai beberapa kelebihan dan kekurangan.
\end{abstract}

Kata Kunci : Mini Cex, metode penilaian, pendidikan tahap klinik

Abstract

Mini Cex is one of assessment method designed to measure the performance of students in the clinical stage education. Mini Cex assessment conducted by an assessor who is trained to student who interact directly with patients, There are seven components which will be evaluated : medical interviewing skills, physical examination skills, professionalism, clinical judgment, counseling skills, organization or efficiency and overall clinical competence. Various studies have shown that mini cex has good validity and reliability, besides this method also has some advantages and disadvantages.

Key word : mini cex, assessment method, clinical stage education 


\section{Pendahuluan}

Sejak tahun 2006, di Indonesia telah ditetapkan Standar Kompetensi Dokter Indonesia (SKDI) sebagai acuan dalam penyusunan kurikulum di setiap institusi pendidikan dokter. Perubahan kurikulum dari kurikulum berdasarkan disiplin ilmu menjadi kurikulum berdasarkan kompetensi juga membawa perubahan pada berbagai aspek termasuk strategi pembelajaran, metode pembelajaran, metode penilaian, kualifikasi sumber daya manusia serta sarana dan prasarana.

Kompetensi adalah seperangkat tindakan cerdas yang dibentuk oleh pengetahuan, keterampilan dan sikap.Kompeten adalah hal yang kontekstual yang merefleksikan kemampuan seseorang untuk menerapkan pengetahuannya dalam stuasi khusus atau situasi yang sesungguhnya. Untuk mengetahui kompeten atau tidaknya peserta didik, perlu dilakukan penilaian yang disebut dengan student assessment.

Sesuai dengan ranah yang membentuk kompetensi, tujuan pembelajaran dibedakan dalam kelompok ranah yaitu pengetahuan, keterampilan dan sikap. Format penilaiannya juga dibedakan, karena tidak ada satu metode penilaian yang benar-benar bisa menilai semuanya. Setiap metode penilaian memiliki kekurangan dan kelebihan.

Tulisan ini akan memaparkan tinjauan pustaka tentang metode penilaian mini cex yang digunakan dalam penilaian performa peserta didik di tahap klinik.

\section{Pengertian}

Mini Cex (Mini Clinical Evaluation Exercise) adalah metode penilaian performa peserta didik pada pendidikan tahap klinik baik kepaniteraan maupun residensi. Metode penilaian ini dirancang untuk menilai keterampilan klinis esensial yang dibutuhkan dalam pelayanan klinik yang baik. Selain itu dalam metode ini terdapat feedback untuk peserta didik yang dapat membantu mengarahkan peserta didik dalam proses pembelajaran. ${ }^{(1)}$

$$
\text { Penilaian dilakukan oleh }
$$
seorang penilai yang sudah dilatih terhadap peserta didik yang berinteraksi langsung dengan pasien dalam setting tertentu, misalnya rawat inap, UGD, poliklinik, dll. Hasil penilaian dituliskan dalam borang penilaian terstruktur oleh penilai, sehingga di akhir penilaian penilai dapat memberikan feedbacknya (contoh borang penilaian terlampir).

\section{Sejarah}

Mini cex dikembangkan pertama kali oleh American Board Internal Medicine (ABIM) pada tahun 1972 untuk menilai kompetensi klinik residen sebagai upaya untuk mengatasi kekurangan metode penilaian Clinical Evaluation Exercise(cex) tradisional. Metode penilaian Cex tradisional mempunyai beberapa kekurangan, seperti :1) Penilaian dilakukan hanya sekali oleh satu orang penilai, 2) Penilaian dilakukan terhadap satu pasien sehingga bersifat case specific, tidak mencerminkan performa secara umum dan 3) Membutuhkan waktu yang lama berhadapan dengan pasien, lebih kurang 2 jam, sehingga menimbulkan ketidaknyamanan pada pasien. ${ }^{(2,3)}$

Untuk mengatasi kekurangan
metode penilaian $\begin{array}{r}\text { tersebut, } \\ \text { dikembangkan mini Cex sebagai } \\ \text { modifikasi dari metode penilaian cex }\end{array}$ modifikasi dari metode penilaian cex penilai menilai residen yang melakukan pemeriksaan terhadap pasien selama 1520 menit, 2) Mini cex dilakukan beberapa kali dalam satu tahun, 3) Mini cex dapat dilakukan dalam berbagai 
settting, misalnya di bangsal, poliklinik, ruang gawat darurat. Dengan demikian peserta didik memiliki kesempatan untuk dinilai oleh beberapa orang penilai dengan kasus pasien yang bervariasi. $^{(2,3)}$

\section{Validitas dan reabilitas}

Penelitian terhadap validitas dan reabilitas mini cex sebagai instrumen penilaian telah dilakukan oleh beberapa orang peneliti di berbagai pusat pendidikan. Penelitian terhadap concurren validity mini cex oleh Durning et al menunjukkan bahwa terdapat korelasi yang bermakna antara penilaian mini cex dengan penilaian bulanan, tetapi kekurangan penelitian ini adalah penilaian mini cex dan penilaian bulanan dilakukan oleh penilai yang sama. Untuk construct validity mini cex, penelitian oleh Holmboe et al menunjukkan bahwa terdapat perbedaan yang signifikan terhadap ketiga kategori penilaian yang digunakan dalam mini cex (tidak memuaskan, memuaskan dan superior) pada tiga kelompok penilaian yaitu anamnesis, pemeriksan fisik dan konseling. Penelitian terhadap reabilitas mini cex menunjukkan hasil yang lebih baik dibandingkan cex tradisional. ${ }^{(2-4)}$

\section{Cara pelaksanaan Mini Cex}

Walaupun dalam sejarahnya, mini cex pertama kali digunakan dalam pendidikan spesialis, tapi dalam perkembangannya mini cex juga dapat digunakan dalam pendidikan tahap klinik bagi peserta didik pada level pendidikan yang lebih rendah misalnya pendidikan tahap klinik program pendidikan dokter. ${ }^{(5)}$

Penilaian mini cex dilaksanakan dengan menggunakan borang terstruktur yang meliputi tujuh kelompok penilaian yaitu $:^{(2)}$

1. Anamnesis
Kemampuan untuk memfasilitasi pasien dalam menjelaskan keadaannya, menggunakan pertanyaan yang sesuai untuk mendapatkan informasi yang adekuat dan memberikan respon verbal dan nonverbal dengan tepat.

2. Pemeriksaan fisik

Kemampuan untuk melakukan pemeriksaan pasien sesuai dengan kasus pasien untuk tujuan skrining atau diagnostik, menjelaskan pada pasien serta sensitif terhadap kenyamanan pasien.

3. Profesionalisme

Kemampuan untuk menunjukkan rasa hormat, kasih sayang, empati, membangun kepercayaan pasien, memperhatikan kenyamanan pasien, rendah hati, menjaga kerahasiaan informasi. Serta menyadari keterbatasan diri.

4. Clinical judgment

Kemampuan untuk menegakkan diagnosis yang tepat, memilih pemeriksaan penunjang yang sesuai dan manajemen dengan memperhatikan keuntungan dan resikonya

5. Keterampilan konseling

Kemampuan untuk menjelaskan rasionalitas pemeriksaan atau pengobatan, mendapatkan persetujuan pasien, melakukan edukasi atau konseling terkait penatalaksanaan pasien.

6. Organisasi atau efisiensi

Kemampuan membuat prioritas dan ringkasan yang jelas.

7. Penilaian secara keseluruhan

Menunjukkan kemampuan secara keseluruhan yang terdiri dari kemampuan membuat sintesis, keputusan klinis,

\section{Kelebihan}

Kelebihan dari metode penilaian mini cex ini adalah $:^{(6-9)}$ 
1. Menilai peserta didik pada level "does" piramid Miller.

2. Menggunakan pasien yang sebenarnya sehingga biaya lebih murah dibandingkan dengan menggunakan pasien simulasi. Selain itu peserta didik juga memiliki pengalaman untuk melihat gejala dan tanda penyakit tertentu pada pasien yang mungkin tidak bisa disimulasikan.

3. Menggunakan beberapa jenis kasus, sehingga penilaian performa mahasiswa dapat dilakukan pada berbagai kasus.

4. Jumlah penilai lebih dari satu dan keputusan penilaian tidak oleh satu orang penilai. Hal ini akan meningkatkan reabilitas instrumen mini cex.

5. Peserta didik mendapatkan feedback dari beberapa penilai untuk meningkatkan performanya

6. Mini cex dilakukan beberapa kali, sehingga memberikan kesempatan pada mahasiswa untuk dapat meningkatkan performanya.

7. Dilakukan pada berbagai setting, sehingga memberi pengalaman pada peserta didik untuk melayani pasien pada berbagai setting.

\section{Kekurangan}

Kekurangan mini cex ini adalah : ${ }^{(8,10)}$

1. Mini cex kurang tepat dalam menilai attitude walaupun ada item profesionalisme, sehingga ada institusi yang telah mengembangkan Professional Mini Evaluation Exercise (P-mex).

2. Sangat tergantung pada jenis kasus yang ditemui pada saat melaksanakan kegiatan, jika kasus kurang, maka kesempatan mahasiswa untuk menemui kasus yang variatif juga kurang.

3. Feedback yang diberikan.

4. Waktu memberikan feedback terbatas karena hanya disediakan waktu 15-20 menit untuk setiap sesi mini cex.

5. Observasi berulang yang dilakukan untuk ujian formatif akan memberikan bias, jika penilai yang sama terlibat dalam penilaian sumatif yang dapat membuat instrumen ini menjadi kurang reliabel.

6. Kurang holistik dibandingkan ujian long case.

\section{Kesimpulan}

Metode student assessment

harus kongruen dengan metode pembelajaran, karena assessment drives learning. Pemilihan metode student assessment juga mangacu pada ranah tujuan pembelajarannya, sehingga diperlukan beberapa metode student assessment dalam suatu program pendidikan. Mini cex adalah salah satu metode student assesment yang cukup efektif dalam menilai performa mahasiswa pada level "does". Metode ini memiliki beberapa kelebihan seperti validitas dan reabilitas yang baik, mahasiswa mendapatkan feedback dari beberapa asesor untuk memperbaiki performanya, memberikan kesempatan yang banyak pada mahasiswa untuk menunjukkan performanya pada berbagai kasus dan setting. Tetapi mini cex juga memiliki kekurangan, sehingga penggunaan instrumen penilaian ini perlu dikombinasi dengan yang lain seperti $P$-mex, OSCE, dll.

\section{KEPUSTAKAAN}

1. Norcini JJ, Blank LL, Duffy D, Fortna GS. The Mini cex : a method for assessing clininal skills. Ann.Intren.Med.2003;138: 476-83.

2. Norcini JJ, Blank LL, Arnold GK, Kimball HR. The mini cex : a preliminary investigation. Ann.Intern.Med.1995; 235:754-9. 
3. Durning SJ, Cation LJ, Mrkert RJ, 7. Aller L. Assess trainees in the Pangaro LN. Assessing the clinical workplace using mini reability and validity of mini cex cex.Education for primary Care. for internal medicine training. 2006;17:270-74. Acad.med.2002;77:900-904.

4. Kogan JR, Bellini LM, Shea JA.

8. Norcini J and Burch V. Workplacebased assessment as an educational Feasibility, reliability and validity of the mini-clinical exercise (mCEX) in a medicine core clerkship. Acad Med 2003;78:S33S35.

5. Kogan JR, Haur KE. Brief report: Use of mini clinical evaluation exercise in Internal Medicine care clerckships. J.Gen.Intern.Med.2006 May;24(5):501-502.

6. Holmboe ES, Yeps M, Williams F, Hout SJ. Feedback and Mini Clinical Evaluation Axercise. J.Gen.Intern.med.2004;19:558-61. tool: AMEE Guide No.31. Medical Teacher.2007; 29:855-871.

9. Alberto Alves de Lima, Diego Conde, Juan Costibel,Juan Carso, CV der Vleuten. A laboratory study on the reability estimations of the mini cex. Ad in Health Sci Educ.2011.

10. Cruess R, Mcllroy JH, Crues S, Ginsburg S, Steinert Y. The Profesionalism Mini-Evaluation Exercise : A Preliminary Investigation. Acad.Med.vol 81; 10;October 2006 supplemen 


\section{Lampiran}

\section{MINI CLINICAL EVALUATION EXERCISE (MINI CEX)*}

Penilai

Tanggal:

Residen:

$\square \mathrm{R}-1$

$\square \mathrm{R}-2$

Masalah/Diagnosis Pasien:.

$\begin{array}{llll}\text { Tempat: } & \square \text { Rawat jalan } \quad \square \text { Rawat inap } & \square \text { UGD } & \square \text { Lain, sebutkan......................... } \\ \text { Pasien } \quad: \quad \quad \text { Umur:....................... } & \text { Jenis Kelamin: L/P } & \square \text { Pasien baru } \quad \square \text { Pasien kontrol } \\ \text { Kompleksitas } \quad: \square \text { rendah } \square \text { sedang } & \square \text { tinggi } & \\ \text { Fokus } \quad: \square \text { anamnesis } \quad \square \text { diagnosis } & \square \text { terapi } & \square \text { konseling }\end{array}$

1. Anamnesis ( $\square$ Tidak diobservasi)
1
$2 \quad 3$
Tidak memuaskan
4

$\stackrel{5}{\text { Memuaskan }}$
6
7
8

\begin{tabular}{cccc}
\hline 2 & Pemeriksaan Fisik ( \\
& 1 & 2 & 3
\end{tabular}

2
Tidak memuaskan

4

$\stackrel{5}{\text { Memuaskan }}$

6

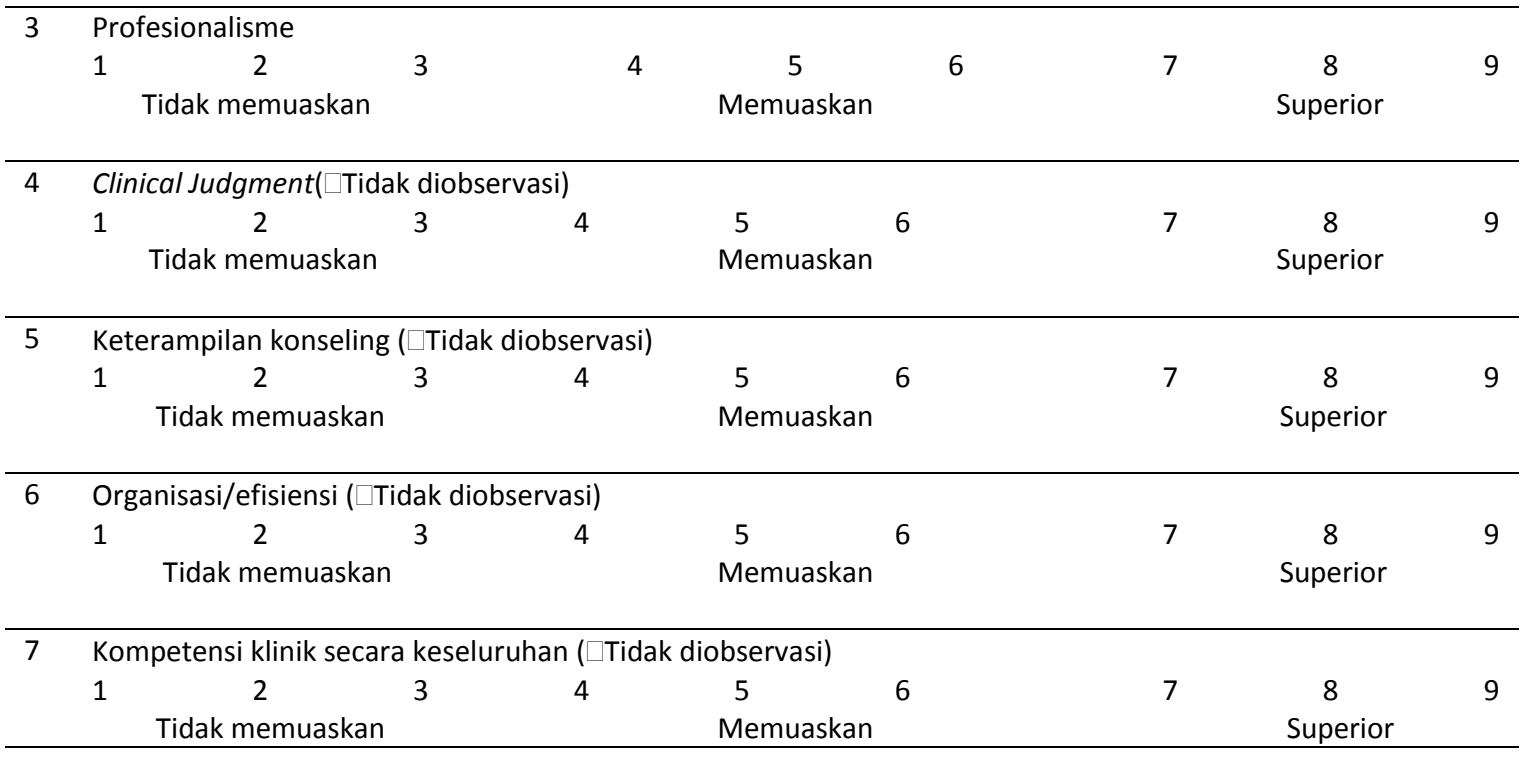

Waktu Mini cex $\quad$ : Observasi....................menit $\quad$ Feedback...........................menit

Kepuasan Penilai terhadap mini cex:

\begin{tabular}{|c|c|c|c|c|c|c|c|c|c|c|}
\hline Rendah & 1 & 2 & 3 & 4 & 5 & 6 & 7 & 8 & 9 & Tinggi \\
\hline \multicolumn{11}{|c|}{ ex: } \\
\hline Rendah & 1 & 2 & 3 & 4 & 5 & 6 & 7 & 8 & 9 & Tinggi \\
\hline
\end{tabular}

Komentar :

Tanda tangan penilai:........................... Tanda tangan residen:....

*Diterjemahkan dari : The appendix figure from Norcini JJ, Blank LL, Arnold GK, Kimball HR. The Mini cex : a preliminary investigation.Ann.Inter.Med.1995;235;754-9 